\title{
Examination the Influence of Human Factors in Indian Building Construction Sites
}

\author{
S. Ajith, C. Sivapragasam and V. Arumugaprabu
}

\begin{abstract}
This research intends to explore the human factors which lead to non-fatal accidents (i.e. first aid case, near miss, lost time injury) and assessing safety supervision factors in building construction sites. A total of hundred non - fatal accident data is collected for the analysis. Human factors such as age, experience, language, education level and competency of the worker are explored using data analysis method. The root causes for the accidents are also determined and it is found that $22 \%$ of the construction site accidents are due to improper supervision. Furthermore a questionnaire survey is conducted among the Safety Engineers, Site Engineers, Supervisors and Workers to elicit the actual happenings about the safety supervision in the site. The questionnaire mainly focused on safety supervision factors and Relative Importance Index (RII) is used to rank the safety factors. As a result, monitoring hoist operation (0.73), moving vehicle (0.72) and checking the stability of scaffolds $(0.69)$ shows higher level of disagreement which means that these factors have been given least priority. In order to measure the strength of relationship between the respondents, Spearman's Rank Correlation is done. Through the Spearman's correlation it is known that Safety Engineers vs Supervisors (0.83) and Safety Engineers vs Site Engineers (0.81) has high correlation values which indicates that these respondents have provided similar rankings.
\end{abstract}

\section{Keywords : Construction, Human factor, Rank Correlation Safety}

\section{INTRODUCTION}

C onstruction sites are known to be hazardous as it records in high level of occupational injuries and casualties. It is also noted that large number of these accidents occurred mainly in commercial and residential building sites [1].The working nature of the construction site workers are unique as they have been engaged in work activities such as change in work environment, height work, hot work, dust, noise etc. To overcome these safety challenges the organizations should adopt innovative strategies to prevent accidents which can be attained through safety Knowledge Management (KM) process [2]. Preventing and protecting the workers from hazards in the site is the major responsibility of the Safety Engineer. Identifying the possible hazards in the site is the key

Revised Manuscript Received on December 05, 2019.

* Correspondence Author

S. Ajith, Department of Civil Engineering, Kalasalingam Academy of Research and Education, Krishnankoil-626126, India. Email: ajith.s@klu.ac.in

C. Sivapragasam, Department of Civil Engineering, Kalasalingam Academy of Research and Education, Krishnankoil-626126, India. Email: sivapragasam@klu.ac.in

V. Arumugaprabu*, Department of Mechanical Engineering, Kalasalingam Academy of Research and Education, Krishnankoil-626126, India. Email: v.arumugaprabu@klu.ac.in step involved in risk management. But some researchers highlighted that identifying the hazards [3] and implementing the safety guidelines alone may not be applicable in preventing or reducing injuries and accidents [4].The execution of risk management system has been increased to minimize the site accidents and injuries. However its functions must be evaluated periodically to ensure that there is no procedural flaws within the existing system [5]. Each and every work related activities where humans are involved have some associated risk or human error. There might not be zero risk in any activity [6]. Human errors such as failing to follow the operating procedures, neglecting to attend safety trainings, inattentive actions leads to accidents [7]. Human error affects both the quality and safety of the organization and also reduces the safety performance [8]. If accidents have to be minimized then it is the duty of every organization to overlook on human error which is the key factor for accidents [9]. Thus a substantial safety program needed to create effective safety climate which assists in minimizing injuries/accidents and leads to the well-being of the workers [10].

\section{A. Previous Studies}

To classify the fatality range, the human factors such as age and gender of the workers were analyzed in construction sites. Numerous occupational injuries data was collected from Council of Labours Affairs (CFA) for a period of three years. From the gender based analysis it is known that male workers (56.4\%) records high fatality rate. The fatalities in the female workers are high in fall from height (39.2\%) and collapse $(10.8 \%)$.Thirteen different types of accident were listed and grouped according to the victim's age [11].

Risk groups in construction sites were examined by categorizing the age and experience of the worker. Through the analysis it is known that workers of age (20-34, > 4 years' experience) contributes one fifth of the total injury. The workers of age 25-29 shows there is an increase in injury rate from 3 to 6 times as compared to the age group of 20-24 \& $30-34$.It is also revealed that the workers of age group (50-54, $>9$ and $<20$ years of experience) records about $70 \%$ injury rate [12].

The contributing factors for construction accidents are unsafe acts, unsafe conditions, unavailability of Personnel Protective Equipment (PPE), lack of risk management and unsuitability of the materials are the main contributing factors [13].

143 construction accident reports were analyzed in order to group the age and work related activities which lead to accident. It is found that workers of age group (35-44) records 42 number of injuries were higher than the age groups. 37 which other 
workers got injury in fingers/hand/wrist which was higher than the injuries in other parts of the body. Finally sprains/strains were the common injuries to the workers when comparing to crushing bruise, foreign body etc [14].

The safety factors in construction sites were assessed using Frequency Adjusted Importance Index (FAII). A questionnaire survey was framed with 40 safety factors in which the respondents were asked to evaluate about the impact and frequency of the particular attributes. FAII was calculated using equation (2).

FAII=RII (in \%) x FI (in \%)

Whereas

$\mathrm{RII}=\left(\left(\sum \mathrm{W}\right) /(\mathrm{A} \times \mathrm{N})\right) \times 100$ (importance)

$\mathrm{FI}=\left(\left(\sum \mathrm{W}\right) /(\mathrm{A} \times \mathrm{N})\right) \times 100$ (frequency) $[15]$.

Spearman's rank correlation test is a nonparametric measure

[16] and a statistical tool which is used to evaluate the potency of relationship between the ranks assigned by different respondents. This test is extensively used in the research area of construction which involves in ranking. The correlation values lies between -1 to +1 . If the value is ' +1 ' then it denotes to be positive and '-1' denotes to be negative correlation [17]. The higher correlation value which approaches to 1 indicates that there is a strong relationship between the two ranks of data sets [18].

A questionnaire survey was conducted with supervisors, clients, contractors, designers and consultants analyzed the factors that affect the safety management in metro construction. The questionnaire consists of 40 attributes with a 5 point scale level of agreement. Factor analysis, ranks, estimating the mean value, one way analysis of variance and Spearman's correlation were computed using SPSS 16.0 [19]. A Behavior Based Safety (BBS) approach was adopted to examine the influence of relations between the supervisors and the workers in construction sites in which the behavior of the workers had been analyzed through the supervisors who have regular and persuasive communications with the site workers. The study revealed that there was a better result in safety climate and the workers behavior [20].

From the previous literatures it is found that human factors were based only on age and experience of the workers. But in India, people from different states with different languages work throughout the country. So languages are the main barrier among the workers and supervisors. It is also known that the task becomes risky as it involves incompetent workers. Therefore educational level and competency of the worker must be considered before assigning a job. In order to fulfil this research gap it is intended to investigate all these human factors in building construction sites. Thus human factors such as language, educational level and competency of the worker are considered with the existing factors. This enhances the human factor analysis and helps us to know the key factors which lead to accidents.

It is noted that human errors which causes accidents in the construction industries are due to the workers and supervisors. It is well known that if there are sufficient supervisors and supervision then accidents can be reduced to as low as possible. Previously researchers have focused only on unsafe acts of the workers. But in this research the safety supervision factors are considered to identify the supervisory errors.

\section{METHODOLOGY}

\section{A. Identification of safety supervision factors}

The Safety Supervision Factors (SSF) is identified after consulting with the Safety Engineers and through intensive literature survey. A total of 15 safety supervision factors are identified in which 7 are the existing factors and 8 more new factors are identified in this research as mentioned in Table I. The significance in considering these factors is that, these are the major roles and responsibilities of a Safety Engineer.

\section{B. Questionnaire Survey}

A questionnaire is framed using the identified safety supervision factor which consists of three level of agreement such as Agree, Rare and Disagree. The respondents include Safety Engineers, Site Engineers, Supervisors and Workers. A total of 66 respondents completed the survey.

\section{Relative importance index}

Relative Importance Index (RII) is used to determine the importance of each factor and rank them accordingly. From RII it can be known the factors which have been given least priority. As the questionnaire survey is from different categories of constructional professionals both the combined and individual ranking is determined for correlation.

\section{Spearman's rank correlation}

In order to determine the strength of relationship between these different respondents, Spearman's rank correlation is used. Spearman's correlation value is found by correlating all the four categories of respondents such as Workers vs Site Engineers, Workers vs Supervisors, Workers vs Safety Engineers, Safety Engineers vs Site Engineers, Safety Engineers vs Supervisors and Site Engineers vs Supervisors. Spearman's correlation value can be calculated from Equation 3.

$$
r=1-\left(\frac{6 \sum d^{2}}{n\left(n^{2}-1\right)}\right)
$$

Whereas,

' $r$ ' is the Spearman's rank correlation between two respondents

' $d$ ' is the assigned ranks

' $\mathrm{n}$ ' is the number of factors.

\section{E. Range of Correlation}

Spearman's correlation range is adopted to classify the respondents' correlation values as mentioned in Table II. The strength of relationship between the respondents can be identified through the correlation range. 
Table I List of factors and their corresponding reference

\begin{tabular}{|c|c|c|}
\hline S.No & \multicolumn{2}{|c|}{ SAFETY SUPERVISION FACTORS } \\
\hline$\overline{\mathrm{SSF}_{1}}$ & \multicolumn{2}{|c|}{ Periodic site inspection } \\
\hline $\mathrm{SSF}_{2}$ & \multicolumn{2}{|c|}{ Tool box talk before the start of work } \\
\hline $\mathrm{SSF}_{3}$ & \multicolumn{2}{|c|}{ Ensuring whether the worker is using suitable $\mathrm{F}$} \\
\hline $\mathrm{SSF}_{4}$ & \multicolumn{2}{|c|}{ Training to the workers } \\
\hline $\mathrm{SSF}_{5}$ & \multicolumn{2}{|c|}{ Performing risk assessment } \\
\hline $\mathrm{SSF}_{6}$ & \multicolumn{2}{|c|}{ Implementing mitigation measures } \\
\hline $\mathrm{SSF}_{7}$ & \multicolumn{2}{|c|}{ Evaluating the implemented mitigation measur } \\
\hline $\mathrm{SSF}_{8}$ & \multicolumn{2}{|c|}{ Monitoring whether the moving vehicles are wit } \\
\hline $\mathrm{SSF}_{9}$ & \multicolumn{2}{|c|}{ Monitoring hoist operation } \\
\hline $\mathrm{SSF}_{10}$ & \multicolumn{2}{|c|}{ Monitoring crane operation } \\
\hline $\mathrm{SSF}_{11}$ & \multicolumn{2}{|c|}{ Issuing work permit } \\
\hline $\mathrm{SSF}_{12}$ & \multicolumn{2}{|c|}{ Conducting safety awareness programs } \\
\hline $\mathrm{SSF}_{13}$ & \multicolumn{2}{|c|}{ Ensuring the worker is using safety harness wh } \\
\hline $\mathrm{SSF}_{14}$ & \multicolumn{2}{|c|}{ Checking the stability of scaffolds } \\
\hline $\mathrm{SSF}_{15}$ & \multicolumn{2}{|c|}{ Ensuring the worker is competent for the partic } \\
\hline \multicolumn{3}{|c|}{ Table II Correlation Range [21] } \\
\hline S.No & Correlation Values & Indication \\
\hline 1. & 0.00 to 0.19 & Very weak \\
\hline 2. & 0.20 to 0.39 & Weak \\
\hline 3. & 0.40 to 0.69 & Moderate \\
\hline 4. & 0.70 to 0.89 & Strong \\
\hline 5. & 0.90 to 1.00 & Very strong \\
\hline
\end{tabular}

\section{ANALYSIS OF NON FATAL ACCIDENTS}

A total of 100 non-fatal construction accident data are collected from building construction sites and are analyzed. Data are classified into different human factors such as age, work experience, educational qualification, competency, language, types of injuries and classification of non-fatal injuries. From the classification it is known that

-Young age workers of age range 18-25 are in higher percentage

-Workers working with less experience of range 0-4 years are higher

$.33 \%$ of the workers are illiterate

$.53 \%$ of the workers are unskilled.

- Cut (33\%) and crush (17\%) injuries are found to occur in higher percentage.

- $51 \%$ of the non-fatal injuries are first aid cases.

As language is considered as the important factor in Indian construction sites, it is found that from Fig.6 there are nearly seven different languages that are spoken by the workers. As a result this will lead to accidents/injuries due to failure in communication. Hence this barrier can be eliminated by providing tool box talk and safety trainings through the languages known to the workers.

The injury rate of the workers is high in the age group of 18-20 and 21-25 as shown in Fig. 1. Also the injury rate is high among the workers at low level of experience that ranges from 0-4 years as shown in Fig. 2. It is suggested that tool box talk must be conducted to the workers before the start of every activity and periodic safety trainings must be organized to reduce the injury rate.

\section{A. Chi square - goodness of fit test}

Chi square test is used to know whether there is significant relationship between two hypotheses. To find the significant relationship between the categorical values, chi square - goodness of fit test is used. In order to know the

REFERENCES

[2], [10], [19]

[2], [10], [19]

[10], [19]

[2], [10], [19]

[13], [19], [22], [23]

[24]

[24]

[Adopted in this research]

[Adopted in this research]

[Adopted in this research]

[Adopted in this research]

[Adopted in this research]

[Adopted in this research]

[Adopted in this research]

[Adopted in this research]

relationship between the hypothesis previous researchers adopted chi square test to determine the significance between the company and the contractor workers with respect to safety in firework industries [25] fatal and non fatal accidents in construction industries [26], injured worker \& claimable fund in the biofuels industry [27]. In this research chi square test as shown in Table III is used to analyze the relationship between the human factors with respect to non-fatal injuries.

Hypothesis

H0: There is no significant relationship between the factors $\mathrm{H1}$ : There is significant relationship between the factors From the chi square test it is known that the chi square values for all the factors are greater than the table value at 0.05 level of significance.

Table III Chi Square Test

\begin{tabular}{llllll}
\hline S.No & Factors & $\begin{array}{l}\text { Degree } \\
\text { of } \\
\text { Freedom }\end{array}$ & $\begin{array}{l}\text { Chi } \\
\text { Square } \\
\text { Value }\end{array}$ & $\begin{array}{l}\text { Level of } \\
\text { Significance }\end{array}$ & $\begin{array}{l}\text { Table } \\
\text { Value }\end{array}$ \\
\hline 1. & $\begin{array}{l}\text { Age vs } \\
\text { Injuries }\end{array}$ & 7 & 46.08 & & 14.07 \\
2. & $\begin{array}{l}\text { Language } \\
\text { vs Injuries }\end{array}$ & 6 & 45.09 & 0.05 & 12.59 \\
3. & $\begin{array}{l}\text { Experience } \\
\text { vs Injuries }\end{array}$ & 4 & 24.8 & & 9.49 \\
4. & $\begin{array}{l}\text { Education } \\
\text { vs Injuries }\end{array}$ & 3 & 15.92 & & 7.82 \\
\hline
\end{tabular}

Therefore, the null hypothesis is rejected and the alternative hypothesis is accepted. So it is said that there is significant relationship between the age groups, language, experience and education with respect to injuries.

\section{B. Determination of root causes for the accidents}

The causes for the accidents are identified by investigating the workers and supervisors. A total of 15 root causes for accidents are identified such as Improper supervision (C1), Fall of material (C2), Hit by object (C3), Failure in communication (C4), Failing to provide PPE (C5), Lapses in procedure (C6), Failure to follow safety procedures (C7), Caught in between (C8), Improper access (C9), No proper barricades (C10), Unsecured materials (C11), Failure to implement work permit (C12), Failing to use PPE (C13), Fail to LOTO (C14), Inexperienced driver (C15). The graph plotted between the different causes for accidents, its percentage and cumulative as shown in Fig. 3 indicates the Pareto $[28,29,30]$ Pareto analysis is a chart. 
statistical tool which is used for decision making. It is also known as $80 \backslash 20$ rule (i.e. major focus must be on $80 \%$ of the causes which lead to risk). From the chart it can be known that the total number of causes which lead to substantial number of risk. Improper supervision, fall of materials, Hit by object and Failure in communication are some of the influential causes for accidents.

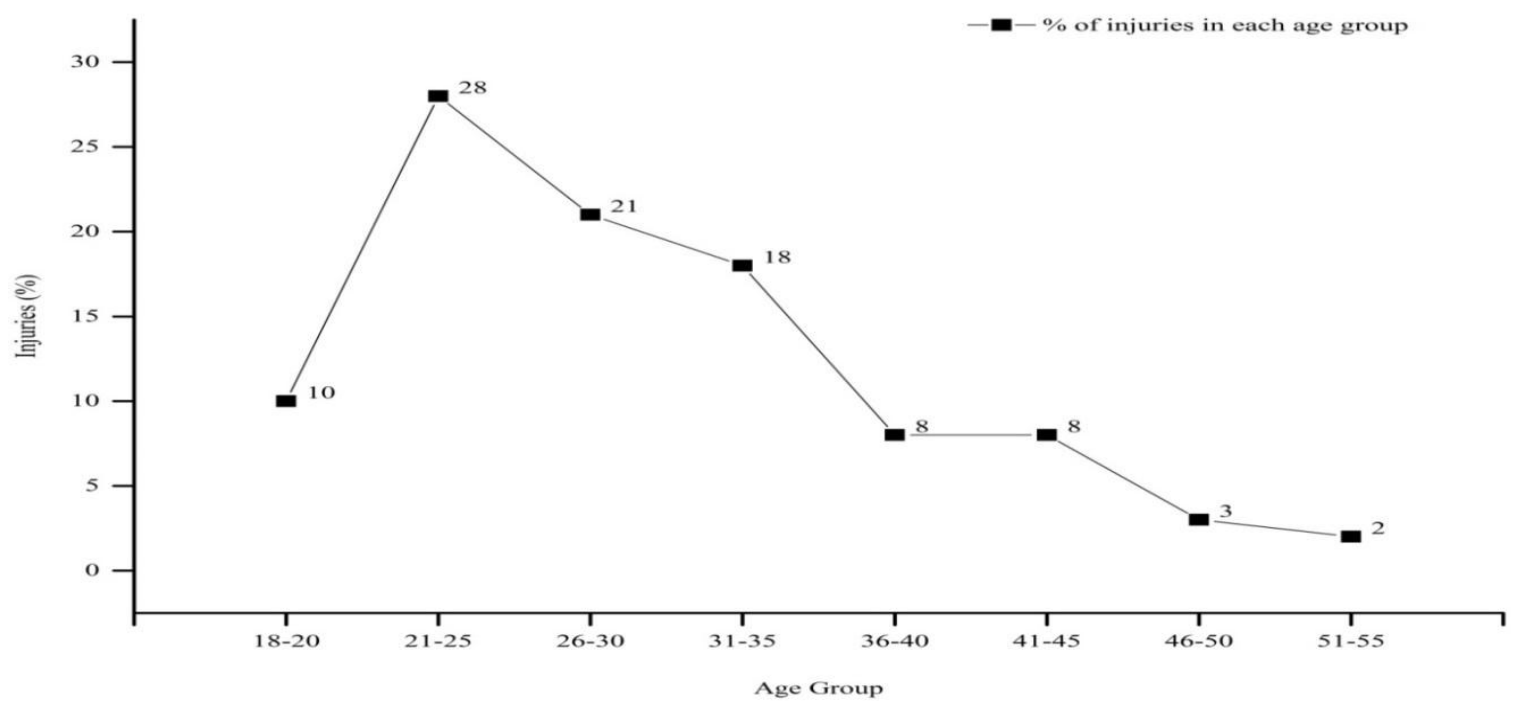

Fig. 1 Percentage of injuries for different age groups

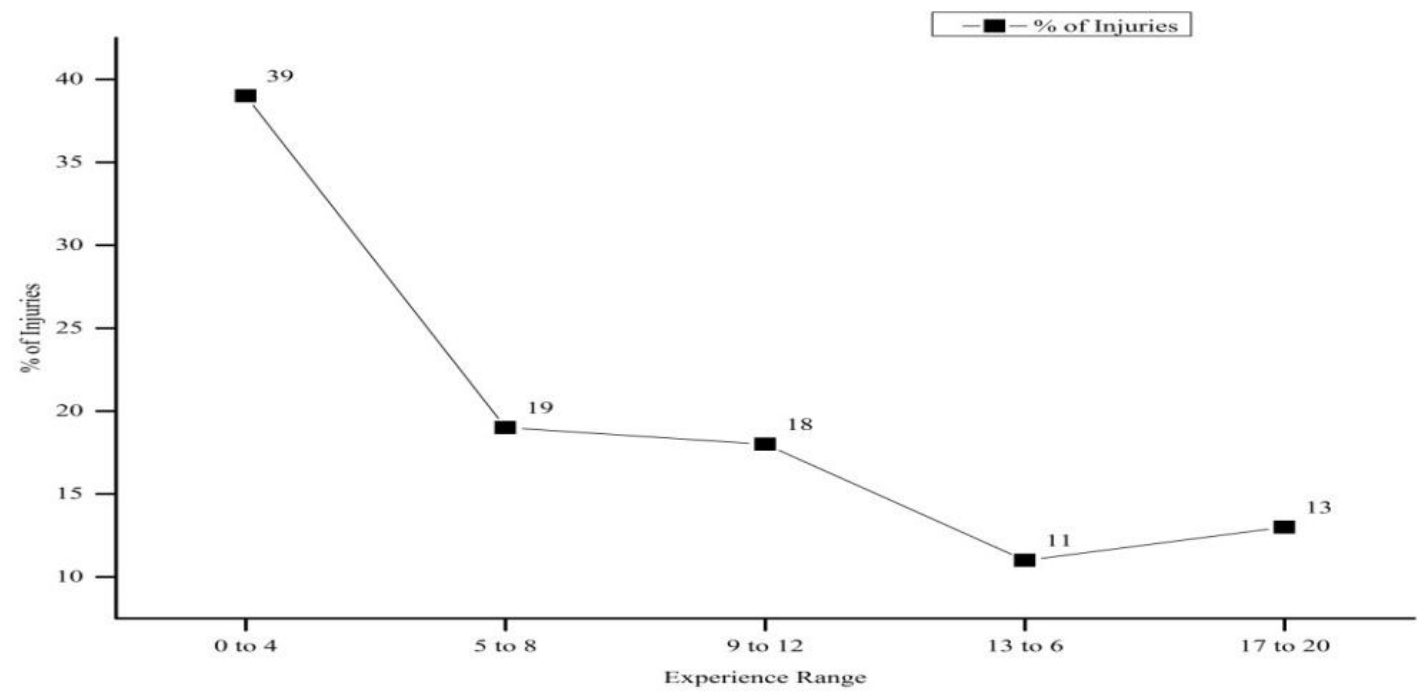

Fig. 2 Injury rate for the experience range

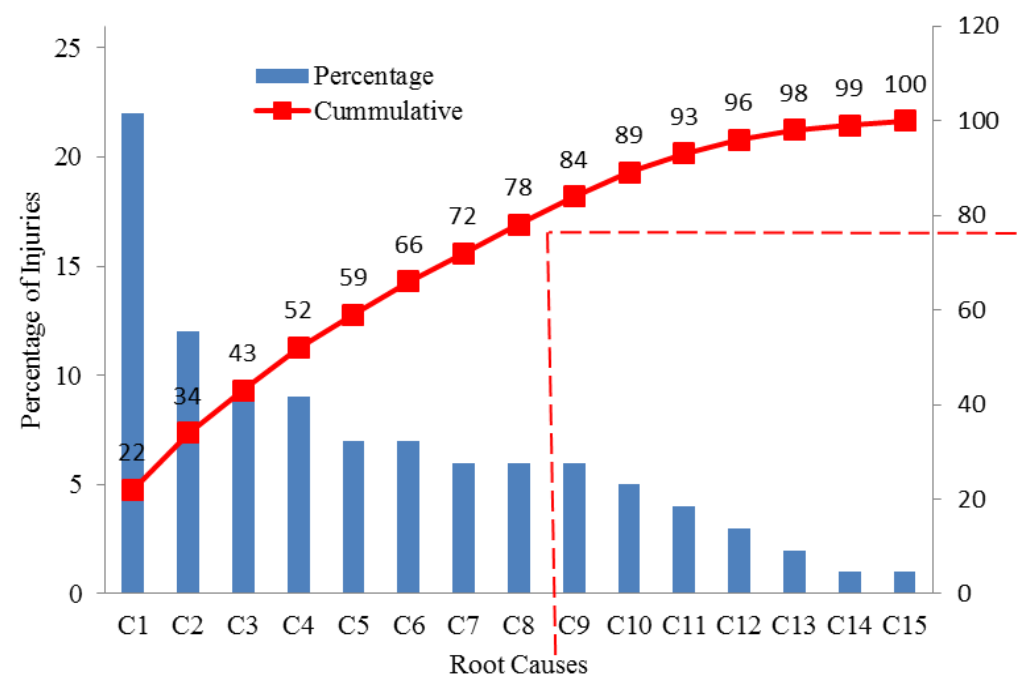

Fig. 3 Root causes for non - fatal accidents 


\section{ANALYSIS OF SAFETY SUPERVISORY FACTORS}

From the root cause analysis it is known that accident rate is high due to improper supervision. Hence it is intended to explore the safety supervision factors which lead to accidents and to know the factors which are neglected by the supervisors. A questionnaire survey is conducted with all the SSF as mentioned in Table 4. A three point Likert scale indicating 1 (Agree), 2 (Rare) and 3 (Disagree) is accompanied with each factors in the questionnaire. From the questionnaire survey and using Equation 1, RII is determined and these factors are ranked to know the most neglected factor. Through the computation, it is known that monitoring the hoist operation (0.73), monitoring the speed limit of the vehicles $(0.72)$ and checking the stability of scaffolds $(0.69)$ are the top three neglected SSF. It is also identified that risk assessment have been performed in sites but implementing and evaluating the mitigation measures are neglected. This is also one of the major reasons for the frequent accidents in high hazardous zone. Therefore it is significant to make sure that the listed SSF in Table IV are to be followed in the site to make each and every task as accident free zone.
Table IV Relative Importance Index

\begin{tabular}{cll}
\hline $\begin{array}{c}\text { SAFETY SUPERVISION } \\
\text { FACTORS }\end{array}$ & \multicolumn{1}{c}{ RII } & \multicolumn{1}{c}{ RANK } \\
\hline $\mathrm{SSF}_{1}$ & 0.40 & 11 \\
$\mathrm{SSF}_{2}$ & 0.42 & 10 \\
$\mathrm{SSF}_{3}$ & 0.45 & 9 \\
$\mathrm{SSF}_{4}$ & 0.39 & 12 \\
$\mathrm{SSF}_{5}$ & 0.48 & 8 \\
$\mathrm{SSF}_{6}$ & 0.53 & 5 \\
$\mathrm{SSF}_{7}$ & 0.64 & 4 \\
$\mathrm{SSF}_{8}$ & 0.72 & 2 \\
$\mathrm{SSF}_{9}$ & 0.73 & 1 \\
$\mathrm{SSF}_{10}$ & 0.49 & 7 \\
$\mathrm{SSF}_{11}$ & 0.38 & 13 \\
$\mathrm{SSF}_{12}$ & 0.49 & 6 \\
$\mathrm{SSF}_{13}$ & 0.37 & 14 \\
$\mathrm{SSF}_{14}$ & 0.69 & 3 \\
$\mathrm{SSF}_{15}$ & 0.36 & 15 \\
\hline & & \\
\hline & & 0.36 \\
\hline
\end{tabular}

\section{A. Determination of individual ranks}

As the questionnaire survey is conducted with different categories of industrial professionals it is targeted to find the correlations between those professionals. Hence RII is found individually and the ranks are assigned accordingly as mentioned in Table $\mathrm{V}$.

Table V RII - Individual Ranks

\begin{tabular}{|c|c|c|c|c|c|c|c|c|}
\hline \multirow{2}{*}{ SSF } & \multicolumn{2}{|c|}{ WORKERS } & \multicolumn{2}{|c|}{ SUPERVISORS } & \multicolumn{2}{|c|}{ SITE ENGINEERS } & \multicolumn{2}{|c|}{ SAFETY ENGINEERS } \\
\hline & RII & RANK & RII & RANK & RII & RANK & RII & RANK \\
\hline 1 & 0.46 & 9 & 0.44 & 11 & 0.33 & 15 & 0.36 & 11 \\
\hline 2 & 0.49 & 7 & 0.33 & 14 & 0.40 & 11 & 0.33 & 13 \\
\hline 3 & 0.43 & 11 & 0.50 & 8 & 0.53 & 5 & 0.38 & 8 \\
\hline 4 & 0.36 & 15 & 0.50 & 8 & 0.42 & 10 & 0.38 & 8 \\
\hline 5 & 0.47 & 8 & 0.67 & 5 & 0.47 & 9 & 0.44 & 7 \\
\hline 6 & 0.53 & 6 & 0.72 & 4 & 0.49 & 7 & 0.47 & 4 \\
\hline 7 & 0.69 & 4 & 0.94 & 2 & 0.53 & 5 & 0.53 & 2 \\
\hline 8 & 0.90 & 1 & 0.67 & 5 & 0.62 & 2 & 0.49 & 3 \\
\hline 9 & 0.89 & 2 & 1.00 & 1 & 0.56 & 4 & 0.47 & 4 \\
\hline 10 & 0.46 & 9 & 0.50 & 8 & 0.58 & 3 & 0.47 & 4 \\
\hline 11 & 0.39 & 12 & 0.33 & 14 & 0.38 & 13 & 0.38 & 8 \\
\hline 12 & 0.56 & 5 & 0.56 & 7 & 0.49 & 7 & 0.36 & 11 \\
\hline 13 & 0.37 & 13 & 0.39 & 13 & 0.40 & 11 & 0.33 & 13 \\
\hline 14 & 0.71 & 3 & 0.78 & 3 & 0.69 & 1 & 0.60 & 1 \\
\hline 15 & 0.37 & 13 & 0.44 & 11 & 0.36 & 14 & 0.33 & 13 \\
\hline
\end{tabular}

\section{B. Spearman's rank correlation}

Spearman's correlation is determined through Equation 3 with the individual ranks and the total number of factors adopted. Finally the values are ranked correspondingly as mentioned in Table VI.

From the correlation range as mentioned in Table 2 it is known that there is a strong relationship between the Safety Engineers vs Supervisors and Safety Engineers vs Site Engineers as they have higher correlation values. The correlation range is moderate between the Workers vs Safety Engineers as they have low correlation values when compared to the other respondents. Hence it can be perceived that Safety Engineers are neglecting some of the safety supervision factors in the workers perception.

Table VI Spearman's Rank Correlation

\begin{tabular}{llll}
\hline S.No & Respondents & $\begin{array}{l}\text { Spearman's } \\
\text { correlation }\end{array}$ & Spearman's rank \\
\hline 1. & $\begin{array}{l}\text { Safety Engineers } \\
\text { vs Supervisors }\end{array}$ & 0.83 & 1 \\
2. & $\begin{array}{l}\text { Safety Engineers } \\
\text { vs Site Engineers }\end{array}$ & 0.81 & 2 \\
3. & $\begin{array}{l}\text { Site Engineers vs } \\
\text { Supervisors } \\
\text { Workers vs }\end{array}$ & 0.76 & 3 \\
4. & $\begin{array}{l}\text { Supervisors } \\
\text { Workers vs Site }\end{array}$ & 0.71 & 4 \\
5. & $\begin{array}{l}\text { Engineers } \\
\text { Workers vs Safety }\end{array}$ & 0.69 & 5 \\
6. & Engineers & 6 \\
\hline
\end{tabular}




\section{CONCLUSIONS}

From this research the following conclusions are drawn

1) One hundred non-fatal accidents are collected and analyzed for the human factors including age of the worker, experience, competency, educational qualification and language. Due to lack of communication and competency there is a possibility for accidents. Hence in this research language and competency are also considered.

2) Data analysis reveals that young age workers with low work experience has higher injury rate.

3) From the root cause analysis it is known that the accident range is high due to improper supervision. So a questionnaire survey is done to explore the safety supervision factors with different industrial professionals. RII is used to calculate the importance of the listed factors.

4) Finally Spearman's rank correlation is done to identify the strength of relationships between different respondents. From Spearman's rank it is known that there is a strong relationship between the Safety Engineers vs Supervisors and Safety Engineers vs Site Engineers. But the relationship between the Workers and the Safety Engineers are moderate and it is concluded that Safety Engineers neglects some of the safety supervisory factors.

\section{REFERENCES}

1. A.P.C. Chan, Y. Yang \& A. Darko, "Construction Accidents in a Large-Scale Public Infrastructure Project: Severity and Prevention". Journal of Construction Engineering and Management, 144(10), 2018, 05018010

2. M.R. Hallowell, "Safety-knowledge management in American construction organizations". Journal of Management in Engineering, 28(2), 2011, pp. 203-211.

3. X. Wang, X. Huang, Y. Luo, J. Pei \& M. Xu, "Improving Workplace Hazard Identification Performance Using Data Mining”. Journal of Construction Engineering and Management, 144(8), 2018, 04018068 .

4. B. Mullan, L. Smith, K. Sainsbury, V. Allom, H. Paterson \& A. L. Lopez, "Active behaviour change safety interventions in the construction industry: A systematic review". Safety science, 79, 2015, pp. 139-148.

5. E. Pereira, U. Hermann, S. Han \& S. AbouRizk, "Case-based reasoning approach for assessing safety performance using safety-related measures". Journal of Construction Engineering and Management, 144(9), 2018, 04018088.

6. M. Kraus, "Risk assessments of contemporary accidents in construction industry". EDP Sciences, In MATEC Web of Conferences Vol. 146, 2018, pp. 03004.

7. A. M. Kumar, S. Rajakarunakaran \& V. A. Prabhu, “Application of fuzzy heart and expert elicitation for quantifying human error probabilities in lpg refuelling station". Journal of Loss Prevention in the Process Industries, 48, 2017, pp. 186-198.

8. J.W. Garrett \& J. Teizer, "Human factors analysis classification system relating to human error awareness taxonomy in construction safety". Journal of Construction Engineering and Management, 135(8), 2009, pp. 754-763.

9. S. A. Shappell \& D. A. Wiegmann, "Applying reason: The human factors analysis and classification system (HFACS)". Human Factors and Aerospace Safety, 2001.

10. T. Aksorn \& B. H. Hadikusumo, "Critical success factors influencing safety program performance in Thai construction projects". Safety science, 46(4), 2008, pp. 709-727.

11. Y. H. Lin, C.Y. Chen \& J. L. Luo, "Gender and age distribution of occupational fatalities in Taiwan". Accident Analysis \& Prevention, 40(4), 2008, pp. 1604-1610.
12. V. Mučenski, I. Peško, J. Dražić, G. Ćirović, M. Trivunić \& D Bibić, "Construction workers injury risk assessment in relation to their experience and age". Procedia engineering, 117, 2015, pp 525-533.

13. R. A. Haslam, S. A. Hide, A. G. Gibb, D. E. Gyi, T. Pavitt, S. Atkinson \& A. R. Duff, "Contributing factors in construction accidents". Applied ergonomics, 36(4), 2005, pp. 401-415.

14. S. D. Choi, "Aging workers and trade-related injuries in the US construction industry". Safety and health at work, 6(2), 2015, pp 151-155.

15. M. Gündüz, Y. Nielsen \& M. Özdemir, "Quantification of delay factors using the relative importance index method for construction projects in Turkey". Journal of Management in Engineering, 29(2), 2012, pp. 133-139.

16. S. M. El-Sayegh \& M. H. Mansour, "Risk assessment and allocation in highway construction projects in the UAE". Journal of Management in Engineering, 31(6), 2015, 04015004.

17. D. W. Chan, A. P. Chan, P. T. Lam, J. F. Yeung \& J. H. Chan, "Risk ranking and analysis in target cost contracts: Empirical evidence from the construction industry". International Journal of Project Management, 29(6), 2011, pp. 751-763.

18. S. M. El-Sayegh, "Risk assessment and allocation in the UAE construction industry". International journal of project management, 26(4), 2008, pp. 431-438.

19. Q. Z. Yu, L. Y. Ding, C. Zhou \& H. B. Luo, "Analysis of factors influencing safety management for metro construction in China". Accident Analysis \& Prevention, 68, 2014, pp. 131-138.

20. P. Zhang, N. Li, D. Fang \& H. Wu, "Supervisor-focused behavior-based safety method for the construction industry: case study in Hong Kong”. Journal of Construction Engineering and Management, 143(7), 2017, 05017009.

21. M. M. Mukaka, "A guide to appropriate use of correlation coefficient in medical research". Malawi Medical Journal, 24(3), 2012, pp. 69-71.

22. M. Hallowell, "Safety risk perception in construction companies in the Pacific Northwest of the USA". Construction management and economics, 28(4), 2010, pp. 403-413.

23. A. Perlman, R. Sacks \& R. Barak, "Hazard recognition and risk perception in construction". Safety science, 64, 2014, pp. 22-31.

24. OHSAS 18001:2007 Occupational Health and Safety Management System - Requirements. ISBN 9780580508028 , July 2007.

25. N. Rajathilagam, "Analysis of safety in fireworks industries by Chi square analysis in Virudhunagar district of Tamilnadu". Int $J$ Manag Soc Sci Res, 2016, 5:32-37.

26. S. Winge \& E. Albrechtsen, "Accident types and barrier failures in the construction industry". Safety science, 105, 2018, pp. 158-166.

27. S. K. Ramaswamy \& G. A. Mosher, "Using workers' compensation claims data to characterize occupational injuries in the biofuels industry". Safety science, 103, 2018, pp. 352-360.

28. S. Al Haadir, \& K. Panuwatwanich, "Critical success factors for safety program implementation among construction companies in Saudi Arabia". Procedia engineering, 14, 2011, pp. 148-155.

29. Y. B. Kurata, D. J. L. Acula, R. L. Galingan, A. M. J. T. Palines \& J C. L. Viterbo, "Human error reduction for cost efficiency improvement in the butchery area of a chicken processing company". Procedia Manufacturing, 3, 2015, pp. 346-353.

30. J. Obolewicz \& A. Dąbrowski, "An application of the Pareto method in surveys to diagnose managers' and workers' perception of occupational safety and health on selected Polish construction sites". International journal of occupational safety and ergonomics, 24(3), 2018, pp. 406-421. 


\section{ANNEXURE I \\ SAMPLE QUESTIONNAIRE}

QUESTIONNAIRE SURVEY FOR IDENTIFYING FACTORS AFFECTING SAFETY SUPERVISION

Name of the Organization:

Designation:
Age:
Name of the Employee:

Experience:

1. Periodic site inspection
a). Strongly agree
b). Agree
c). Strongly disagree
e). Disagree

2. Tool box talk before the start of work
a). Strongly agree
b). Agree
c). Strongly disagree
e). Disagree

3. Ensuring whether the worker is using suitable PPE
a). Strongly agree
b). Agree
c). Strongly disagree
e). Disagree
4. Training to the workers
a). Strongly agree
b). Agree
c). Strongly disagree
e). Disagree

5. Performing risk assessment
a). Strongly agree
b). Agree
c). Strongly disagree
e). Disagree

6. Implementing mitigation measures
a). Strongly agree
b). Agree
c). Strongly disagree
e). Disagree

7. Evaluating the implemented mitigation measures
a). Strongly agree
b). Agree
c). Strongly disagree
e). Disagree

8. Monitoring whether the moving vehicles are within the speed limit.
a). Strongly agree
b). Agree
c). Strongly disagree
e). Disagree

9. Monitoring hoist operation
a). Strongly agree
b). Agree
c). Strongly disagree
e). Disagree

10. Monitoring crane operation
a). Strongly agree
b). Agree
c). Strongly disagree
e). Disagree

11. Issuing work permit
a). Strongly agree
b). Agree
c). Strongly disagree
e). Disagree

12. Conducting safety awareness programs
a). Strongly agree
b). Agree
c). Strongly disagree
e). Disagree

13. Ensuring the worker is using safety harness while working at height.
a). Strongly agree
b). Agree
c). Strongly disagree
e). Disagree

14. Checking the stability of scaffolds
a). Strongly agree
b). Agree
c). Strongly disagree
e). Disagree

15. Ensuring the worker is competent for the particular work
a). Strongly agree
b). Agree
c). Strongly disagree
e). Disagree

\section{AUTHORS PROFILE}

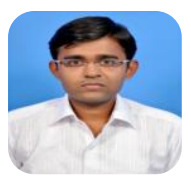

Mr. S. Ajith has completed his graduation and post-graduation from KTVR Knowledge Park for Engineering \& Technology and University Departments of Anna University respectively. Currently he is a research scholar at Kalasalingam Academy of Research and Education, India.

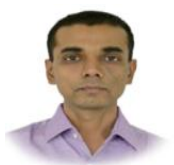

Dr. C.Sivapragasam has completed his graduation and post-graduation from IIT-Roorkee and IIT-Delhi respectively. He completed his $\mathrm{PhD}$ from NUS, Singapore. He has 2 years of industry experience and more than 17 years of teaching experience. He has completed 3 sponsored research projects from various funding agencies and published more than 70 papers in peer reviewed journals and conferences.

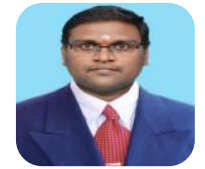

Dr. V. Arumugaprabu has completed his graduation in Mechanical Engineering and post-graduation in CAD/CAM from Arulmigu Kalasalingam College of Engineering and Mepco Schlenk Engineering College respectively. He completed his $\mathrm{PhD}$ from Kalasalingam Academy of Research and Education, India. He has 12 years of teaching experience. He has completed 1 sponsored research project from funding agencies and published more than 80 papers in peer reviewed journals and conferences. 